\title{
Heterogeneity matters: temporary employment, productivity and wages in Italian firms
}

\author{
Valeria Cirillo $^{1}$ (D) Andrea Ricci ${ }^{2}$
}

Received: 23 September 2019 / Accepted: 24 August 2020 / Published online: 5 September 2020

(c) The Author(s) 2020

\begin{abstract}
This study analyses the relationship between flexible employment, productivity and wages, along their distributions. We use an original firm-level dataset, which combines information on workplace characteristics from Rilevazione su Imprese $e$ Lavoro (RIL) with the Analisi Informatizzata delle Aziende Italiane (AIDA) balance sheet information for the universe of Italian non-agriculture/financial corporations. We employ different quantile regression models to panel data and find, first, that use of temporary contracts is associated to a reduction in labour productivity and wages at each point in the corresponding distribution; and second, that the negative relationship between labour productivity and wages decreases in magnitude along the quantiles of the productivity and wage distributions, suggesting that low-productive/ low-wage firms use temporary employment to permanently staff positions and to compress labour costs.
\end{abstract}

Keywords Labour productivity · Wages · Temporary employment $\cdot$ Firm-level analysis · Quantile regressions

JEL Classification $\mathrm{J} 2 \cdot \mathrm{J} 24 \cdot \mathrm{J} 31 \cdot \mathrm{L} 25$

\section{Introduction}

Productivity growth has been weak in Italy since the late 1990s. Several concurrent phenomena contribute to explaining the slowdown of productivity growth in the Italian economy including segmentation of the productive system as the result of increasing firm heterogeneity (Bugamelli et al. 2018). The empirical evidence suggests that there are two groups of firms. One is characterized by a large population

Valeria Cirillo

valeriacirillo@hotmail.it

1 Department of Political Sciences, University of Bari “Aldo Moro”, Piazza Cesare Battisti 1, 70121 Bari, Italy

2 National Institute for Public Policies Analysis, INAPP, Corso d'Italia, 33, 00198 Rome, Italy 
of micro-enterprises with a low propensity to invest in innovation and human capital and internationalization, and weak financial structures. The other is a relatively small group of firms, mostly medium and large-sized, whose efficiency, performance and productive strategies are comparable to European competitors (Dosi et al. 2012; Calligaris et al. 2016).

Average wages have either stagnated or declined since the 1990s and were disrupted in a major way by the 2008 financial crisis. However, the dispersion of wages both within and between firms (and sectors) has increased significantly over time (Card et al. 2018; International Labour Organization 2017). This is evidence of the coexistence of high-wage and low-wage firms which is reflected in the increasing segmentation and heterogeneity of their productive behaviours.

The economic literature provides extensive discussion of sources of the observed changes to labour productivity, the wages distribution and the increased role of firm heterogeneity. They range from supply side explanations, such as the shortage of skilled workers, to demand side explanations such as lack of investment in new technologies and inefficient management practices.

The present study contributes to this debate by focusing on the potential consequences of labour market reforms that, over the last decades, have reduced the employment protection legislation for new hires and, de facto, liberalized firms' exploitation of flexible work arrangements. The share of employees covered by fixed-term contracts almost doubled from $7.2 \%$ of total employment in 1995 to $17 \%$ in 2018 (OECD 1999, 2003). Labour market flexibility is seen as a solution to the negative effects of the 2008 economic crisis and a means of dealing with structural unemployment.

There are multiple arguments to consider. On the one hand, temporary contracts may favour the matching between supply of and demand for labour, especially when firms are facing significant changes to the business cycle (Houseman 2001), and may allow more efficient screening and selection of productive workers, which would improve productivity and wages (Wang and Weiss 1998; Autor 2001). On the other hand, temporary hirings can affect firm performance by: (1) altering the incentives to invest in specific inputs, including human capital (Arulampalam et al. 2004; Booth et al. 2002; Acemoglu and Pischke 1999; Ricci and Waldmann 2015); and (2) weakening the firm's organizational capabilities, which are embedded in the firm's procedural knowledge (Dosi et al. 2019). Knowledge accumulation relies on long-lasting employment relationships, allowing the development of training opportunities and increased job specific experience. At the same time, if flexible work arrangements have an adverse effect on labour productivity and wages, intense use of short-term working arrangements could contribute to increasing the segmentation of the Italian production structure and deepening the divide between high-productive and low-productive firms and high-paying and low-paying firms.

In sum, hypothetically, firms could use temporary employment in at least three ways: "reactive use"-temporary workers are used to deal with unexpected fluctuations in demand; "planned use"-to augment the regular workforce and to allow for expected changes; and "systematic use" which means all staff are on temporary contracts. In the former two cases, there might be a positive association between temporary employment and labour productivity since the 
detrimental effect on knowledge accumulation is likely to be balanced by a better selection of more productive workers or adaptation to fluctuating demand. In the third case of systematic and continuous use of temporary employees to staff all positions, productivity is likely to decrease through disinvestment in human capital and weakening of the firm's organizational capabilities (see among others, Abraham and Taylor 1996; Houseman 2001; Vidal and Tigges 2009; Aleksynska and Berg 2016).

Against this background, we aim to provide evidence of an association between increasing use of numerical flexibility at the firm level-that is, intensive use of flexible work arrangements - and labour productivity and wages, taking explicit account of the differences in productivity levels and the wages paid to workers across businesses.

We examine the association between use of temporary contracts and productivity, focusing on how it varies along the conditional productivity distribution. Low-productive and high-productive firms use flexible working for different reasons: in highly-productive firms, temporary contracts can be a stepping stone to more stable employment in the firm, but in less-productive firms, systematic use of flexible arrangements is more likely as part of a cost-cutting strategy.

We exploit original, firm-level data from the 2007, 2010 and 2015 Rilevazione su Imprese e Lavoro (RIL) survey, conducted by INAPP (National Institute for Public Policies Analysis), for a representative sample of partnership and limited liability firms, and merge these data with balance sheet information from AIDA (Analisi Informatizzata delle Aziende Italiane) provided by the Bureau Van Dijk. We estimate different quantile regressions based on the panel data (Parente and Silva 2016; Canay 2011), to take account of the role of firm heterogeneity in shaping temporary contracts along the entire productivity and wage distributions.

We found, first, that intensive use of temporary contracts is correlated to reduced labour productivity and wages at each point in the corresponding distributions. Second, we found that the magnitude of the negative estimates associated with fixed term contracts decreases along the productivity and wage distribution quantiles, suggesting that it is mainly low-productive/low-wage firms that resort to temporary employment to permanently staff positions, possibly to try to reduce labour costs. In the case of the most productive firms - those in the 90th percentile-the estimates are negligible in magnitude and statistically not significant, suggesting that these firms may use fixed-term contracts to screen new hires and/ or as the step towards a permanent position. Third, our results are quite robust to sectoral specialization and firm size, which suggests that the diffusion of temporary contracts interacts with firms' competitive and behavioural heterogeneity in shaping the evolution of the labour productivity and wage distributions.

The remainder of the paper is organized as follows. Section 2 discusses previous evidence on temporary employment, wages and labour productivity, emphasizing those studies that, in some way, explicitly consider the role of firm heterogeneity. Section 3 presents the data and descriptive statistics. Section 4 introduces the econometric strategy and Sect. 5 presents the main results. Section 6 concludes. 


\section{Firm heterogeneity and temporary work: background discussion}

Labour flexibility has increased across Europe in recent years, in an attempt to boost employment and productivity. By favouring adjustment of the labour supply to changing market conditions, greater flexibility was expected to have a positive impact on employment and to foster productivity dynamics by easing the entry and exit of workers ensuring a better match between the demand for and supply of skills (OECD 1994; European Commission 2007).

Since the 1994 OECD Jobs Study, which put the case for reduced employment protection legislation in order to reduce unemployment, academic research in this area has increased. Many studies point to a relationship between poor labour market performance and employment protection (Layard et al. 1991; Scarpetta 1996; Siebert 1997; Nickell 1997; Nickell et al. 2005). Another steam of work finds no such relationship (Howell et al. 2007; Schömann 2014; De Stefano 2014; Avdagic 2015; Baccaro and Rey 2007) although the empirical findings appear sensitive to the countries and time periods compared (Piasna and Myant 2017).

Economic labour theory highlights several channels through which temporary employment affects labour productivity. In contexts of labour market imperfections and asymmetric information (among others see Waldman 1984; Lazear 1986; Gibbons and Katz 1991), temporary contracts are used to screen new workers to allow permanent recruitment of only the most productive ones. Firms cannot observe employees productivity before they are hired; the abilities and skills of young workers prior to entry to the labour market are unknown, which makes use of fixed-term contracts to allow screening of new employees more likely (Wang and Weiss 1998). This implies that, during the probation period, the employee has an incentive to increase his/her effort in order to get an open-ended contract. Firms that offer permanent contracts only to the most productive workers, improve their chances of increasing their overall productivity (Engellandt and Riphahn 2005; Gerfin et al. 2005; Addison and Surfield 2009; Boockmann and Hagen 2008; Gash 2008; McGinnity et al. 2000, 2005). However, using fixedterm employment to substitute for the core workforce can have a negative effect on workers' motivation and result in lower labour productivity (Brown and Sessions 2005). The literature concludes that moderate use of fixed-term contracts should increase labour productivity due to screening and positive motivational effects, but excessive adoption of fixed term contracts can be detrimental to workers' motivation. Related studies theorize about "high-trust" human resources management practices and that long-lasting working relations imply commitment between employees and employers which boosts productivity (Lorenz 1992; Buchele and Christiansen 1999; Naastepad and Storm 2006).

Another potential explanation for the link between fixed-term contracts and productivity relies on human capital theory in the context of imperfect labour markets (Acemoglu 1997; Acemoglu and Pischke 1998, 1999). Assuming adverse selection in the market, firms have an incentive to increase their workers' productivity by investing in increasing their human capital — through training-on the assumption that post-training productivity grows more than workers' wages 
(Bassanini et al. 2007). In the case of short-term contracts, firms have little incentive to invest in human capital; decreased investment in specific human capital is accompanied by reduced labour productivity (Arulampalam et al. 2004; Booth et al. 2002; Zwick 2006; Brunello et al. 2005). A similar argument holds in the context of workers who are induced to invest in firm-specific skills if they expect the employment relationship to endure, but are more likely to invest in general skills if they perceive the risk of losing their job is high (Wasmer 2006). These ideas assume a link between flexible employment and both worker and firm productivity, based on low incentive to invest in firm-specific skills (Guell and Petrongolo 2007, for Spain; Blanchard and Landier 2002, for France).

Focusing, still, on knowledge accumulation, although not necessarily via training, evolutionary studies (Dosi et al. 2001) highlight that workers are key actors in the firm's knowledge base and capabilities developments. Over time, workers accumulate process-specific experience and refine their ability to perform tasks and solve problems, thereby contributing to the accumulation of firm capabilities. Rapid turnover of workers reduces the firm's organizational capabilities, which are nested in the organization's procedural knowledge (Dosi et al. 2019). Building on this argument, Lucidi and Kleinknecht (2010) suggest that the accumulation of firm-specific knowledge is hampered by the presence of flexible labour. They show that use of flexible labour is associated to cost reduction strategies and reduces firm productivity growth.

Although high rates of turnover-due to temporary employment-might improve job and search mechanisms, weaken human capital by altering the firm's and its workers' incentives to invest in training or reduce the firm's organizational capabilities; this varies across sectors and countries (Hall and Soskice 2001). Estevez-Abe et al. (2001) focus on institutional heterogeneities and suggest that social protection and employment protection, in particular, are associated to national competitive advantage in international markets and national product market strategy choices. Firms' product market choices are constrained by the availability of specific skills; skilled employees require appropriate forms and levels of social protection, specifically, employment protection. Product market strategies require different types of skills, that is, firm-specific skills, industry-specific skills or general skills, each of which differs in terms of asset-specificity and portability. For instance, firm-specific skills are of value only to the focal firm and, convincing the workers to invest in such skills will require a high level of employment protection (Aoki 1988). Therefore, in economies where the firm's product market strategy involves firm and industry specific skills, employment protection benefits both skilled workers and firms. Conversely, if the firm is engaged in mass production of standardized goods and has no need for specific skills, it will have little interest in offering employment protection. This literature envisages two different welfare-production regimes: weak employment protection and a general skills profile such as in the Anglo-Saxon countries and Ireland and strong employment protection and firm/industry-specific skills typical of some continental European countries and Japan. Italy falls into the second group, which emphasizes employment protection and creation of firm-specific skills.

In this context, firm heterogeneity can play an important role. Several authors provide evidence of persistent productivity differences across firms-even in 
narrowly defined industries (Syverson 2011). Large and persistent productivity dispersion has been linked to features such as technology, demand, market structure (Syverson 2004; Schmitz 2005), sunk costs (2010) and organizational structure (Maksimovic and Phillips 2002; Schoar 2002; Hortaçsu and Syverson 2007). The labour economics literature associates different levels of productivity to workers' human capital (Abowd et al. 2005), use of incentive pay (Lazaer 2000) and various human resources and managerial practices (Ichniowski and Shaw 2003; Bloom and Van Reenen 2007). The issue of productivity differences has received attention, also, from the trade literature, which shows that the impacts of trade vary across producers according to their level of productivity (e.g., Eaton and Kortum 2002; Melitz 2003).

The evolutionary theory of the firm considers that labour productivity dispersion arises from specific organizational forms and capabilities, which are difficult for the firm to acquire in the short-term, such as innovation, engagement in international transactions, exporting and patenting (Winter 1987; Dosi et al. 2008, 2012; Kleinknecht 2020). Differences in capabilities might explain interfirm productivity dispersion (Teece 2019) and reducing the capabilities gap can be challenging for the firm.

We do not pretend to provide an exhaustive review of the literature or debate the ultimate causes of the productivity gaps across firms or interfirm wage differences. Rather, we focus on exploring the role of firm heterogeneity in shaping temporary employment and its effect along the productivity and wage distributions.

High-productive and low-productive firms might have different reasons for choosing temporary employment contracts. A "reactive" and "planned" approach would involve short-term use of temporary employees to fill regular positions in periods of staff sickness or peak demand, or as part of a probationary period (Vidal and Tigges 2009). Reactive and planned uses of temporary employees might be a stage in the journey to a permanent contract with the firm. In contrast, a "systematic approach" to numerical flexibility refers to long-term use of temporary positions during any period and is in line with the "dead end" hypothesis (Both et al. 2002). As already argued, there are various theoretical reasons why labour flexibility reduces the incentive for innovation (Lucidi and Kleinknecht 2010; Cetrulo et al. 2019; Hoxha and Kleinknecht 2020) while increasing competition based on "low road" practices (Osterman 2018) such as cutting labour costs, maintaining low-productive jobs and reducing training activities. This cluster of low-productive firms survived the 2008 financial crisis.

The clear heterogeneity across firms (Haltiwanger et al. 1999; Bartelsman and Dooms 2000; Syverson 2011) increased after the 2008 crisis, which contradicts the "cleansing-hypothesis" that recessions force the exit of the least productive firms which increases productivity (Caballero and Hammour 1994; Siu and Jaimovich 2012; Foster et al. 2016). The reallocation of firms across industries seems to have a modest effect in the case of Italy and involves, mostly, incorporated firms or firms with more than 20 employees (Linarello and Petrella 2017).

The extreme polarization of the Italian productive system has been well-documented (Bugamelli et al. 2018). Dosi et al. (2012), in the case of manufacturing firms during the period 1989-2004, find that heterogeneity in the productivity 
distribution has increased, driven by the left tail-that is, the cluster of low productive firms - and high persistence in the relative positioning on the productivity ladder.

Regardless of the reason for this segmentation of Italian business firms, segmentation needs to be taken into account and might reflect different strategies related to use of temporary employment. If reactive and planned approaches prevail, we should find a positive association between incremental use of temporary employment and labour productivity_intense usage of temporary contracts might not reflect wage compression tout court. Conversely, if a systematic approach dominates, we can expect a negative relationship between temporary positions and labour productivity, reflected, also, by wage compression. We expect the first approach to affect high-productive and high-paying firms and the second to apply to low-productive and low-paying firms.

Several studies involve empirical analysis of the relationship between labour flexibility and productivity behaviour (measured as both labour productivity and total factor productivity) or the firm's innovation activity. However, most conduct country or sectoral analyses (Buchele and Christiansen 1999; Nickell and Layard 1999; Bassanini and Ernst 2002; Naastepad and Storm 2005; Damiani et al. 2016; 2018) and only a few provide firm-level evidence. In particular, Michie and Sheenan (1999) study the impact of various flexibility practices on indicators of innovation, among British firms, and find a negative effect of external flexibility and a positive effect of functional flexibility. Kleinknecht et al. (2006) in a sample of Dutch firms, find similar results for labour productivity growth. Arvanitis (2005) uses data on Swiss firms and estimates the relationship between temporary work and average labour productivity, measured as sales per employee; however, he finds no statistically significant relationship. Arvanitis (2005) first identifies heterogeneity in human capital intensity and finds a positive relationship between temporary work and labour productivity, but only in firms with high human capital intensity. In contrast, he finds that flexible work arrangements are correlated negatively to labour productivity in low human capital intensity firms.

Few studies explicitly consider the role of heterogeneity across firms and sectors, although there are some that focus on heterogeneity in terms of technological opportunities and technological regimes (Cetrulo et al. 2019; Hoxha and Kleinknecht 2020).

The theoretical and empirical literature also studies the relationship between fixed-term contracts and wages, mainly from a micro perspective and without emphasizing the role of wage heterogeneity among firms, which, in turn, corresponds to a variety of technological patterns and firm opportunities. It seems that more productive firms also pay the highest wages.

The present analysis focuses on how adoption of short-term contractual arrangements affects both labour productivity and wages. As already noted, explanations that link workers' contractual arrangements to workers' wages are mainly microbased, rely on different arguments, but offer no structural interpretation of the mechanisms possibly underpinning and connecting flexible work to both labour productivity and wages. 
It has been suggested that wages tend to be higher and grow faster in industries with higher technological opportunities (Acemoglu 2002; Chennells and Van Reenen 2002). If so, we would expect high-paying firms to correspond to high-productive firms where flexible employment is not used to achieve some form of wage compression.

\section{Data and descriptive statistics}

The empirical analysis is based on three waves of the Rilevazione Imprese e Lavoro (RIL) conducted by INAPP (National Institute for Public Policies Analysis) during 2007, 2010 and 2015, on a representative sample of partnership and limited liability firms. ${ }^{1}$ Each survey wave includes over 25,000 firms operating in the non-agricultural private sector. A subsample of these firms (around 35\%) is followed over time, which, during the period analysed, means that some of the RIL data are panel data.

Each wave of the RIL survey provides rich information on employment composition and personnel organization (types of contracts, training activities, etc.), industrial relations and other workplace and firm productive characteristics. However, information on the financial and accounting variables were retrieved from another source. We used national tax numbers to merge RIL data with AIDA (Analisi Informatizzata delle Aziende Italiane) archival data provided by the Bureau Van Dijk. AIDA data offer comprehensive balance sheet information for almost all (except agricultural and financial) Italian private sector corporations. In particular, these data include yearly values for variables such as revenue, added value, net profit, book value of physical capital, total wage bill and raw-materials expenditure. Consequently, we have indicators of labour productivity (value added per employee), wages (total labour cost per employee), fixed capital (total amount of physical assets per employee) and other balance sheet variables (raw materials expenditure, net profits, etc.). ${ }^{2}$

The resulting merged RIL-AIDA sample is restricted to limited liability firms that disclose detailed accounts in accordance with EEC Fourth Directive. Our sample selection includes firms with at least one employee sampled in the RIL survey. After excluding firms with missing information for the key variables and deleting those with labour productivity and wages values in both the right (99.5 percentile) and left ( 0.05 percentile) tails of the corresponding distributions, we obtained a longitudinal RIL-AIDA sample of approximately 2600 firm-year observations over the period 2007-2015..$^{3}$

\footnotetext{
${ }^{1}$ The RIL survey sample is stratified by size, sector, geographic area and firm's legal form. For more detail on the RIL questionnaire, sample design and methodological issues see INAPP (2017): https:// www.inapp.org/it/ril

${ }^{2}$ These financial variables are deflated using the deflators provided by the national statistics institute (ISTAT).

${ }^{3}$ Note the cross-sectional counterpart of our RIL-AIDA panel sample includes 8633 firms in 2007, 11,166 firms in 2010 and 14,813 in 2015.
} 
Table 1 Labour productivity and wages by quantiles and year (in logarithms). Whole sample

\begin{tabular}{lllllrrr}
\hline & \multicolumn{2}{l}{ Labour Productivity $(\log )$} & & \multicolumn{3}{l}{ Wages $(\log )$} \\
\cline { 2 - 3 } \cline { 7 - 8 } & 2007 & 2010 & 2015 & & 2007 & 2010 & 2015 \\
\hline Mean & 10.81 & 10.72 & 10.56 & & 10.27 & 10.28 & 10.16 \\
q10 & 10.17 & 10.04 & 9.85 & & 9.71 & 9.67 & 9.48 \\
q25 & 10.48 & 10.4 & 10.22 & & 10.06 & 10.07 & 9.97 \\
q50 & 10.81 & 10.71 & 10.6 & & 10.32 & 10.33 & 10.33 \\
q75 & 11.15 & 11 & 10.95 & & 10.55 & 10.56 & 10.58 \\
q90 & 11.52 & 11.43 & 11.31 & & 10.74 & 10.77 & 10.83 \\
\hline
\end{tabular}

RIL-INAPP 2007-2010-2015. Sampling weights applied

\subsection{Descriptive statistics}

Table 1 presents descriptive statistics for the labour productivity and labour cost distributions for each sample year. Both high-productive and low-productive firms registered a decline in labour productivity over time and over the crisis (2007-2010). Over the whole period, labour productivity declined by $0.32 \mathrm{log}$ points in low-productive firms and by $0.21 \mathrm{log}$ points in high-productive firms. The decline was faster in low-productive firms both during the crisis (2007-2010) and in the post-crisis period (2010-2015). High-productive firms saw a reduction in labour productivity both during the crisis $(-0.09)$ and in the post-crisis period $(-0.12)$. These figures are consistent with those from the cross-sectional sample, that is, a decline in labour productivity of 0.17 log points, on average, over 2007-2015 (see Appendix Table A1). ${ }^{4}$

The evolution of labour costs reflects the productivity pattern: labour costs decreased below the median, but, for the last decile, were stable or even increased $(0.09)$, mostly over the last two years $(0.06)$. To the extent that the labour productivity distribution mimics the labour cost distribution, it seems that low-productive firms reacted to the crisis by reducing wages from 2010, while high-productive firms maintained their wage levels both during the crisis (2007-2010) and in the postcrisis period (2010-2015). Wages remained fairly stable over the period, with the exception of low-paying firms, where wages slightly decreased and high-paying firms which show a modest increase in wages. The results for the cross-sectional sample are similar (see Appendix Table A1).

Small firms deserve particular attention, due to the composition of the sample and the weight of small firms in the Italian economy. Table 2 presents descriptive statistics for the sub-sample of small firms. Both productivity and wage dynamics

\footnotetext{
${ }^{4}$ If we consider the cross-sectional component of RIL and multiply it by the sampling weight per employment to obtain aggregate figures, we find that labour productivity decreased by $5 \%$ during $2007-$ 2014. The contraction in labour productivity is concentrated in low productive $(-20 \%)$ rather than high productive firms $(-5 \%)$.
} 
Table 2 Labour productivity and wages by quantiles and year (in logarithms). Small firms

\begin{tabular}{llllllrr}
\hline & \multicolumn{2}{l}{ Labour Productivity $(\log )$} & & \multicolumn{2}{l}{ Wages $(\log )$} \\
\cline { 7 - 8 } & 2007 & 2010 & 2015 & & 2007 & 2010 & 2015 \\
\hline Mean & 10.79 & 10.71 & 10.55 & & 10.25 & 10.26 & 10.15 \\
q10 & 10.15 & 10.02 & 9.85 & & 9.69 & 9.67 & 9.48 \\
q25 & 10.47 & 10.39 & 10.21 & & 10.03 & 10.06 & 9.97 \\
q50 & 10.79 & 10.7 & 10.6 & & 10.3 & 10.32 & 10.33 \\
q75 & 11.14 & 10.99 & 10.94 & & 10.53 & 10.55 & 10.57 \\
q90 & 11.52 & 11.43 & 11.3 & & 10.72 & 10.75 & 10.82 \\
\hline
\end{tabular}

RIL-INAPP 2007-2010-2015. Sampling weights applied

\begin{tabular}{|c|c|c|c|c|c|c|}
\hline & \multicolumn{2}{|l|}{2007} & \multicolumn{2}{|l|}{2010} & \multicolumn{2}{|l|}{2015} \\
\hline & Mean & $\mathrm{SD}$ & Mean & SD & Mean & $\mathrm{SD}$ \\
\hline \multicolumn{7}{|c|}{ Labour productivity } \\
\hline 1 quantile & 0.17 & 0.26 & 0.16 & 0.26 & 0.07 & 0.20 \\
\hline 2 quantile & 0.12 & 0.25 & 0.11 & 0.16 & 0.08 & 0.21 \\
\hline 3 quantile & 0.08 & 0.18 & 0.11 & 0.21 & 0.03 & 0.1 \\
\hline 4 quantile & 0.07 & 0.15 & 0.09 & 0.18 & 0.05 & 0.14 \\
\hline 5 quantile & 0.05 & 0.14 & 0.05 & 0.14 & 0.07 & 0.18 \\
\hline \multicolumn{7}{|l|}{ Labour costs } \\
\hline 1 quantile & 0.18 & 0.31 & 0.22 & 0.3 & 0.09 & 0.24 \\
\hline 2 quantile & 0.13 & 0.21 & 0.11 & 0.2 & 0.11 & 0.24 \\
\hline 3 quantile & 0.06 & 0.12 & 0.06 & 0.14 & 0.04 & 0.11 \\
\hline 4 quantile & 0.09 & 0.18 & 0.05 & 0.11 & 0.03 & 0.08 \\
\hline 5 quantile & 0.04 & 0.11 & 0.06 & 0.14 & 0.03 & 0.09 \\
\hline
\end{tabular}

RIL-INAPP 2007-2010-2015. Sampling weights applied

The share of temporary employees ranges between 0 and 1 . Values need to be multiplied by 100 to get percentages

are observed in this sub-sample with a declining trend for labour productivity over time that is most pronounced in the lowest part of the labour productivity distribution $(-0.3)$. Wages in low paying firms declined over time $(-0.21)$, but show an increase in the upper part of the distribution (0.1), similar to medium and mediumlarge firms.

Table 3 displays the mean and standard deviation of the share of employees under fixed-term contracts across different quantiles of the productivity and labour cost distributions. The share of fixed-term contracts is higher in the lower quantiles of both the labour productivity and labour cost distributions. Low-paying and low-productive firms use temporary employment more often. The average share of temporary employment for the most productive firms at the top of the distribution (q90) 
is about $6 \%$ over the entire time span. ${ }^{5}$ We see a trend towards decreased temporary employment from 2007 to 2015 in both high- and low-productive firms and highand low-paying firms. However, this decline is faster in low-productive compared to high-productive firms, due, most likely, to job destruction experienced by lowproductive firms over the period which affected workers covered by short-term work arrangements (OECD 2019). At the top of the labour productivity distribution (q90), the share of temporary employees increased by 2 percentage points after 2008, with high-productive firms preferring temporary hirings.

Overall, the share of fixed term contracts is significantly higher among low-productive and low-paying firms compared to high-productive and high-paying firms. Low-productive and low-paying firms are smaller and less capital intensive than high-productive firms; they operate in low-tech sectors such as wholesale trade, social services, textiles, tobacco and food. High-productive firms, on average, have a higher proportion of executives and white-collar workers and more performance related pay schemes. These firms are concentrated in the chemicals, mechanical and business services sectors (see Appendix Tables A4, A5 and A6).

Is there an association between an increase in the proportion of temporary employees in the workplace and labour productivity in both high-productive and low-productive firms? Is there the same association between firm-level wages in high-paying and low-paying firms? We address these questions in what follows.

\section{Econometric strategy}

Given the wide dispersion in both productivity and wages among firms, we adopt a quantile regression approach. Quantile regression, originally developed by Koenker and Bassett (1978), provides an understanding of the relationship between fixed term contracts and firm performance, along the entire productivity and wage distributions. We propose the following econometric specifications:

$$
\begin{gathered}
\ln (\text { labprod })_{i, t}=\alpha_{\theta} \cdot F T_{i, t}+\beta_{\theta} \cdot X_{i, t}+\eta_{i}+\varepsilon_{i, t} \\
\ln (\text { wage })_{i, t}=\alpha_{\theta} \cdot F T_{i, t}+\beta_{\theta} \cdot X_{i, t}+\eta_{i}+\varepsilon_{i, t}
\end{gathered}
$$

where $\ln (\text { labprod })_{i, t}$ and $\ln (\text { wage })_{i, t}$ are the (log) value added per employee and the (log) labour cost per employee, respectively; $F T_{i, t}$ is the share of fixed term contracts ranging from 0 to 1 ; and the vector $\mathrm{X}_{i, t}$ controls for a set of firm characteristics (physical capital, firm age, sector of activity, size, macro-region, vacancies, mergers and acquisitions, product and process innovations, employer associations, etc.) and employment composition (gender, professional status, contractual arrangement). ${ }^{6}$

\footnotetext{
${ }^{5}$ Appendix Table A2 presents the distribution of temporary employees by quantiles and years for the cross-sectional sample. Low-productive and low-paying firms employ a higher share of temporary employees each year.

${ }^{6}$ Appendix Table A3 provides a detailed list and descriptive statistics for the variables included in the analysis.
} 
The parameter $\eta_{i}$ denotes the firms' time-invariant unobserved heterogeneity and $\varepsilon_{i t}$ is an error term capturing the idiosyncratic component of labour productivity in (1) and wages in (2). Finally, the vectors of the coefficients $\alpha_{\theta}, \beta_{\theta}$, are estimated at each of chosen quantiles $\theta=0.1,0.25,0.5,0.75$ and 0.9 of the outcome variable.

Within this econometric framework, we start by performing a quantile regression with robust and clustered standard errors to control for heteroscedasticity and autocorrelation within firms across the distribution (Machado and Santos Silva 2000; Parente and Santos-Silva 2016). We then employ the simple two-step procedure proposed by Canay (2011) to control for time-invariant firm-specific unobserved heterogeneity. Following this, the estimation is carried out controlling for fixed effects on the assumption that these effects are pure location shifters across the productivity (wage) distribution. In our case, the first step is used to estimate unobserved fixed effects using a standard within fixed effects estimator in Eqs. (1) and (2). In the second step, the consistently estimated fixed effects are used to reduce the (log of) labour productivity (or alternatively the log of wages) and this transformed (adjusted) measure is used as the dependent variable to conduct standard conditional quantile regression of Eqs. (1) and (2). ${ }^{7}$

We acknowledge that there might be some selection of firms into intensive use of flexible contractual arrangements, due to the firms' productive and behavioural characteristics (size, sectoral specialization, type of corporate governance, etc.). Further economic uncertainty and/or wage or productivity shocks could result in changes in the share of fixed-term employees who are the first to be affected by firings in the case of a negative productivity shock. This firm level selection mechanism potentially could bias our estimates. We try to address this endogeneity problem by: (1) including a wide set of observed explanatory variables; and (2) controlling for firm specific time invariant unobserved heterogeneity using Canay's (2011) technique.

Indeed, this strategy does not ensure the resolution of biases related to firm timevariant unobserved heterogeneity. In particular, there may be upward biases in the quantile estimates, whether use of temporary contracts is correlated negatively to technology adoption, evolution of implicit social norms in the workplace or efficient managerial practices and, as a consequence, with unobserved productivity. In sum, our econometric framework does not allow us to infer causal relationships, but our estimated correlations control for a large set of firm observed and time-invariant unobserved heterogeneity. ${ }^{8}$

\footnotetext{
7 We also estimate Eqs. (1) and (2) using a Quantile Regression estimator for Panel Data (QRPD) with non-additive fixed effects, i.e., assuming the non-separable disturbance term associated with quantile estimation (Powell 2016). Although QRPD is straightforward to implement, it is computationally burdensome. For this reason, we use conditional quantile models with additive fixed effects (Caney 2011; Koenker 2004) rather than an unconditional quantile model with non-additive fixed effects (Powell 2016).

8 It is worth noting that, without applying specific decomposition techniques (Machado and Mata 2005; Firpo, Fortin and Lemieux 2009), wage estimates could confound pure price effects and compositional changes in workforce characteristics. In turn, these changes could produce potential biases in the estimation of Eq. (2). On the other hand, relying on quantile regression models for panel data allows a better understanding how the link between firm heterogeneity and use of fixed term contracts contributes to shaping the evolution of the wage (and productivity) distribution.
} 
Table 4 Pooled quantile estimates (Santos Silva technique). Whole sample

\begin{tabular}{|c|c|c|c|c|c|c|}
\hline & q10 & $\mathrm{q} 25$ & $\mathrm{q} 50$ & $\mathrm{q} 75$ & q90 & OLS \\
\hline \multicolumn{7}{|l|}{ Panel A: lab productivity } \\
\hline Share of FT contracts & $\begin{array}{l}-0.590^{* * *} \\
{[0.109]}\end{array}$ & $\begin{array}{l}-0.419 * * * \\
{[0.072]}\end{array}$ & $\begin{array}{l}-0.282 * * * \\
{[0.042]}\end{array}$ & $\begin{array}{l}-0.125^{* * *} \\
{[0.047]}\end{array}$ & $\begin{array}{l}-0.107 \\
{[0.078]}\end{array}$ & $\begin{array}{l}-0.329 * * * \\
{[0.055]}\end{array}$ \\
\hline Other controls & Yes & Yes & Yes & Yes & Yes & Yes \\
\hline Constant & $\begin{array}{l}9.352 * * * \\
{[0.113]}\end{array}$ & $\begin{array}{l}9.511 * * * \\
{[0.142]}\end{array}$ & $\begin{array}{l}9.531 * * * \\
{[0.14]}\end{array}$ & $\begin{array}{l}9.691 * * * \\
{[0.316]}\end{array}$ & $\begin{array}{l}10.732 * * * \\
{[0.151]}\end{array}$ & $\begin{array}{l}9.893 * * * \\
{[0.312]}\end{array}$ \\
\hline $\mathrm{N}$ of Obs & 8228 & 8228 & 8228 & 8228 & 8228 & 8228 \\
\hline $\mathrm{R} 2$ & 0.231 & 0.259 & 0.274 & 0.255 & 0.229 & 0.278 \\
\hline \multicolumn{7}{|l|}{ Panel A: wages } \\
\hline Share of FT contracts & $\begin{array}{l}-0.695 * * * \\
{[0.094]}\end{array}$ & $\begin{array}{l}-0.577 * * * \\
{[0.044]}\end{array}$ & $\begin{array}{l}-0.457 * * * \\
{[0.036]}\end{array}$ & $\begin{array}{l}-0.338^{* * *} \\
{[0.034]}\end{array}$ & $\begin{array}{l}-0.196^{* * * *} \\
{[0.064]}\end{array}$ & $\begin{array}{l}-0.473 * * * \\
{[0.046]}\end{array}$ \\
\hline Other controls & Yes & Yes & Yes & Yes & Yes & Yes \\
\hline Constant & $\begin{array}{l}9.525 * * * \\
{[0.124]}\end{array}$ & $\begin{array}{l}9.800 \text { *** } \\
{[0.108]}\end{array}$ & $\begin{array}{l}10.120 * * * \\
{[0.088]}\end{array}$ & $\begin{array}{l}10.654 * * * \\
{[0.083]}\end{array}$ & $\begin{array}{l}11.425 * * * \\
{[0.308]}\end{array}$ & $\begin{array}{l}10.134 * * * \\
{[0.217]}\end{array}$ \\
\hline $\mathrm{N}$ of Obs & 8278 & 8278 & 8278 & 8278 & 8278 & 8278 \\
\hline $\mathrm{R} 2$ & 0.271 & 0.3 & 0.307 & 0.274 & 0.212 & 0.316 \\
\hline
\end{tabular}

RIL-INAPP 2007-2010-2015 longitudinal sample. Other control variables: employment composition (gender, executives, blue collars, white collars, training, hirings, immigrants), vacancy, product innovation, process innovation, merger and acquisitions, firms' age, sector of activity, macro-region, employers' membership, performance related pay. Robust (booststrapped) standard errors in parentheses: $* * *$ $p<0.01, * * p<0.05, * p<0.1$

\section{Main results}

Table 4 presents the results for the pooled quantile regressions for Eqs. (1) and (2).

In more detail, Table 4 panel A presents the quantile estimates across the labour productivity distribution. We see that a higher share of short-term contracts is associated negatively to labour productivity along the productivity distribution. We observe that the share of fixed-term employees is related significantly and negatively to labour productivity in the 10th, 25th, 50th and 75th quantiles of the productivity distribution by respectively $-0.59,-0.41,-0.28$ and -0.12 , meaning that a one unit (1 percentage point) increase in the fixed term contract ratio in the firm is associated with a decrease in productivity of about $0.003 \%$. $^{9}$ This is in line with previous work -in the case of Belgian firms, Garnero et al. (2014) find a correlation of 0.046 , although not significant. ${ }^{10}$ No significant effect emerges for the upper tail

\footnotetext{
9 The share of fixed term contracts ranges between 0 and 1 , the coefficients need to be divided by 100 to be interpreted as percentages.

10 Appendix Table A7 presents the results for the cross-sectional component. The relationship between the share of fixed-term contracts and labour productivity/wage remains negative and significant along both the labour productivity and wage distributions. The magnitude of the coefficients is decreasing along the distributions.
} 
of the labour productivity distribution, namely the 90th quantile, suggesting a nonuniform relationship along the whole distribution. For less productive firms-in the 10th quantile - an increase of one percentage point in the share of fixed-term contracts reduces labour productivity by $0.006 \%$.

Firms at the median of the productivity distribution-50th quantile-are also characterized by a negative association between an increase in the share of temporary employees and labour productivity; specifically, a one percentage point increase in the share of employees on fixed-term contracts reduces productivity by $0.003 \%$. Conversely, at the top of the productivity distribution (i.e., the most productive firms), the relationship between fixed-term contracts and labour productivity no longer holds, meaning that more productive firms are not affected by incremental use of short-term employment while a potential vicious cycle between use of fixedterm contracts and low productivity emerges for low productive firms. ${ }^{11}$

Table 4 panel B presents the pooled quantile estimates for the labour cost distribution (wages).

Here, we observe a negative correlation between the share of employees on fixed term contracts and the firm's labour costs, for each quantile. In detail, the negative relationship between the share of fixed term contracts and wages is decreasing along the distribution while productivity is equal to -0.7 at 10th quantile, -0.57 at the 25 th quantile, -0.45 at the median, -0.33 at the 75 th quantile and -0.19 at the 90th quantile. In low-paying firms, incremental use of fixed-term contracts is strongly and negatively associated to the average wage, while in high-paying firmsin the 90th quantile-we observe a weaker relationship between use of fixed-term contracts and average wages. These results are consistent with previous empirical evidence of the existence of a wage differential between permanent and fixed-term workers.

Combining results in Table 4 panels $\mathrm{A}$ and $\mathrm{B}$, to the extent that the distribution of labour productivity mimics the labour cost distribution, it seems that a higher share of fixed-term employees in a high productive firm is not associated to reduced labour productivity, but is associated to a $0.002 \%$ wages reduction. Conversely, in low productive firms, a higher percentage of fixed-term workers is associated to a sharp decrease in labour productivity and compresses the average firm wage by almost $0.007 \%$. In high productive firms, incremental use of short-term work arrangements is not associated to labour productivity. Short-term workers are paid more in highproductive firms, which is in line with previous empirical studies showing a smaller wage gap between high-skilled permanent and fixed-term workers compared to

\footnotetext{
11 We do not test explicitly for the vicious cycle hypothesis but propose this argument to interpret our results. Indeed, considering the distribution of fixed-term workers among firms and the magnitude of the fixed-term coefficient, which varies substantially, we argue that those firms with a higher share of temporary jobs (also the less productive firms) are exposed to a higher negative effect compared to highproductive firms.
} 
Table 5 FE quantile estimates (Canay technique). Whole sample

\begin{tabular}{|c|c|c|c|c|c|c|}
\hline & $\mathrm{q} 10$ & $\mathrm{q} 25$ & q50 & q75 & q90 & FE \\
\hline \multicolumn{7}{|l|}{ Panel A: lab productivity } \\
\hline Share of FT contracts & $\begin{array}{l}-0.386^{* * *} \\
{[0.037]}\end{array}$ & $\begin{array}{l}-0.284 * * * \\
{[0.023]}\end{array}$ & $\begin{array}{l}-0.217 * * * \\
{[0.012]}\end{array}$ & $\begin{array}{l}-0.149 * * * \\
{[0.023]}\end{array}$ & $\begin{array}{l}-0.068 \\
{[0.043]}\end{array}$ & $\begin{array}{l}-0.229 * * * \\
{[0.061]}\end{array}$ \\
\hline Other controls & Yes & Yes & Yes & Yes & Yes & Yes \\
\hline Constant & $\begin{array}{l}10.873 * * * \\
{[0.276]}\end{array}$ & $\begin{array}{l}10.846^{* * * *} \\
{[0.292]}\end{array}$ & $\begin{array}{l}11.023^{* * *} \\
{[0.032]}\end{array}$ & $\begin{array}{l}11.101 \text { *** } \\
{[0.054]}\end{array}$ & $\begin{array}{l}11.209^{* * *} \\
{[0.158]}\end{array}$ & $\begin{array}{l}10.980^{* * * *} \\
{[0.291]}\end{array}$ \\
\hline $\mathrm{N}$ of Obs & 8228 & 8228 & 8228 & 8228 & 8228 & 8228 \\
\hline $\mathrm{R} 2$ & 0.809 & 0.817 & 0.818 & 0.816 & 0.81 & 0.22 \\
\hline \multicolumn{7}{|l|}{ Panel A: wages } \\
\hline Share of FT contracts & $\begin{array}{l}-0.482^{* * * *} \\
{[0.038]}\end{array}$ & $\begin{array}{l}-0.371 * * * \\
{[0.019]}\end{array}$ & $\begin{array}{l}-0.306^{* * * *} \\
{[0.008]}\end{array}$ & $\begin{array}{l}-0.219^{* * * *} \\
{[0.017]}\end{array}$ & $\begin{array}{l}-0.138 * * * \\
{[0.025]}\end{array}$ & $\begin{array}{l}-0.316^{\text {**** }} \\
{[0.060]}\end{array}$ \\
\hline Other controls & Yes & Yes & Yes & Yes & Yes & Yes \\
\hline Constant & $\begin{array}{l}10.741 * * * \\
{[0.046]}\end{array}$ & $\begin{array}{l}10.884^{* * * *} \\
{[0.033]}\end{array}$ & $\begin{array}{l}10.958^{* * * *} \\
{[0.056]}\end{array}$ & $\begin{array}{l}11.180^{* * * *} \\
{[0.034]}\end{array}$ & $\begin{array}{l}11.381^{* * * *} \\
{[0.166]}\end{array}$ & $\begin{array}{l}11.039^{* * * *} \\
{[0.145]}\end{array}$ \\
\hline $\mathrm{N}$ of Obs & 8278 & 8278 & 8278 & 8278 & 8278 & 8278 \\
\hline $\mathrm{R} 2$ & 0.876 & 0.884 & 0.885 & 0.882 & 0.876 & 0.308 \\
\hline
\end{tabular}

RIL-INAPP 2007-2010-2015 longitudinal sample. Other control variables: employment composition (gender, executives, blue collars, white collars, training, hirings, immigrants), vacancy, product innovation, process innovation, merger and acquisitions, firms' age, sector of activity, macro-region, employers' membership, performance related pay. Robust (booststrapped) standard errors in parentheses: *** $p<0.01, * * p<0.05, * p<0.1$

low-skilled ones in more productive firms. ${ }^{12}$ Our estimates tend to support the idea of strategic use of flexible staff arrangements by firms, to sustain profitability even when labour productivity is declining. Intensive use of temporary work allows lowproductive firms to survive in the market, pursuing a strategy of cost-competitiveness based on wage compression.

\subsection{Fixed effects}

Table 5 presents the quantile fixed effect estimates of Eqs. (1) and (2) obtained using the two-step procedure proposed by Canay (2011).

\footnotetext{
${ }^{12}$ The results in Table 4 are derived by including a rich set of explanatory variables in Eqs. (1) and (2). E.g., we find that in the lower part of the corresponding distribution firm size is positively related to productivity. In high productive firms, size is not associated with labour productivity, highlighting that the firm dimension is a crucial feature of low productive firms. As expected, physical assets by employee are positively related to labour productivity, in both high and low productive firms. We also include a set of controls related to workers' characteristics, such as share of female workers, share of executives, shares of white and blue collar workers. We consider a set of controls related to firm age, sector of activity, location, being part of a multinational,- -and firm performance in terms of introduction of product/process innovations. The estimates related to these controls are available upon request.
} 
Table 5 panel A indicates that the magnitude of the estimated coefficients decreases across the labour productivity distribution, confirming the pattern in Table 4: the negative sign associated with the share of fixed-term contracts is equal to -0.38 at the 10th quantile, -0.28 at the 25th quantile, -0.21 at the median and -0.14 at the 75th quantile of the labour productivity distribution; at the 90th quantile, we observe a non-significant correlation. ${ }^{13}$ That is, in high-productive firms (90th quantile), there is no detrimental effect of temporary employment on labour productivity. This can be explained, in part, by the composition of the workforce in high-productive firms. Even controlling for occupations, it is likely that high-productive firms employ high-productive workers and that temporary employees are highly qualified. Another explanation might be related to the type of short-term contract used by high-productive firms; they might resemble a passport for entry to a more permanent position (Berton et al. 2011). If so, then, on the one hand, a short-term contract will not affect workers' motivation or reduce labour productivity and, on the other hand, will have no effect on firm training programmes or on the accumulation of firm-level capabilities.

Similarly, Table 5 panel B shows that the effect of fixed term contracts reduces the (log of) labour cost with decreasing magnitude along the distribution. Specifically, we observe that the share of fixed-term employees is associated to lower average wages. An increasing share of short-term employees reduces the average wage more in low-paying firms than in high-paying firms. ${ }^{14}$

To sum up, the empirical analysis suggests some duality in the Italian production structure based on the simultaneous presence of low-paying/low-productive firms and high-paying/ high-productive firms whose use of short-term work arrangements is associated differently to labour productivity and wages. An additional source of heterogeneity which potentially might be affecting the temporary employment-productivity/wage relationship might be related to structural and organizational differences among small, medium and medium-large firms, as indicated in the RIL-sample on training and labour productivity discussed in Dosi et al. (2018). Below we focus on small firms.

\subsection{Small firms}

In this section we replicate the previous analysis for the subsample of small firms with less than 50 employees, which are characterized by some specific features.

Table 6 reports the pooled quantile estimates for Eqs. (1) and (2).

Panel A shows that an increasing share of fixed-term employment is associated to lower average firm productivity along the whole of the distribution and including high-productive firms which contrasts with the results in Table 4 for the 90th quantile. However, in small firms the negative effect associated with the share of temporary contracts is stronger in low- than in high-productive firms.

Similarly, Table 6 panel B indicates that increasing use of fixed-term employment reduces the average firm wage more in low paying firms, confirming the general

\footnotetext{
13 The fact that the pooled results are (in absolute terms) larger than the fixed effects results might indicate the existence of selection of our firms into short-term work making the fixed effects estimates more reliable than the pooled estimates.

14 Recall that our estimates do not allow us to infer causal relationships, only correlations.
} 
Table 6 Pooled quantile estimates. Firms with less than 50 employees

\begin{tabular}{llllll}
\hline & $\mathrm{q} 10$ & $\mathrm{q} 25$ & $\mathrm{q} 50$ & $\mathrm{q} 75$ & $\mathrm{q} 90$ \\
\hline Panel A: lab productivity & & & & & \\
Share of FT contracts & $-0.695^{* * *}$ & $-0.512^{* * *}$ & $-0.346^{* * * *}$ & $-0.238^{* * *}$ & $-0.163^{*}$ \\
& {$[0.104]$} & {$[0.083]$} & {$[0.043]$} & {$[0.059]$} & {$[0.086]$} \\
Other controls & Yes & Yes & Yes & Yes & Yes \\
Constant & $9.495^{* * *}$ & $9.458^{* * *}$ & $9.673^{* * *}$ & $9.947 * * *$ & $10.707^{* * *}$ \\
& {$[0.174]$} & {$[0.114]$} & {$[0.392]$} & {$[0.308]$} & {$[0.121]$} \\
N of Obs & 6443 & 6443 & 6443 & 6443 & 6443 \\
R2 & 0.16 & 0.215 & 0.236 & 0.221 & 0.191 \\
Panel B: wages & & & & & \\
Share of FT contracts & $-0.812^{* * * *}$ & $-0.650^{* * *}$ & $-0.512^{* * *}$ & $-0.400^{* * *}$ & $-0.248^{* * *}$ \\
& {$[0.095]$} & {$[0.049]$} & {$[0.037]$} & {$[0.042]$} & {$[0.049]$} \\
Other controls & Yes & Yes & Yes & Yes & Yes \\
Constant & $8.733^{* * *}$ & $9.551^{* * *}$ & $9.882^{* * *}$ & $10.188^{* * * *}$ & $10.482^{* * *}$ \\
& {$[2.689]$} & {$[0.165]$} & {$[0.129]$} & {$[0.336]$} & {$[0.080]$} \\
N of Obs & 6487 & 6487 & 6487 & 6487 & 6487 \\
R2 & 0.208 & 0.241 & 0.255 & 0.227 & 0.16 \\
\hline
\end{tabular}

RIL-INAPP 2007-2010-2015. Note: Other control variables: employment composition (gender, executives, blue collars, white collars, training, hirings, immigrants), vacancy, product innovation, process innovation, mergers and acquisitions, firms' age, sector of activity, macro-region, ecc), employers' association, performance related pay. Robust (boostrapped) standard errors in parentheses; *** $p<0.01$, ** $p<0.05, * p<0.1$

pattern identified for the whole sample. These findings are substantially confirmed by quantile fixed effects estimates-see Table 7.

The dynamics identified for the whole sample apply, also, to most small firms, although not the high-productive small firms where productivity is negatively related to incremental use of short-term work arrangements which does not apply to the case of high-productive medium-large firms.

\section{Conclusion}

Since 2010, implementation of labour market reforms in the Italian labour market has been aimed at increasing labour flexibility to improve labour productivity and facilitate allocative efficiency (Martin and Scarpetta 2012). In this context, Bugamelli et al. (2018) highlight that two recent Italian reforms significantly changed the functioning of labour market and increased its allocative efficiency. However, a detrimental effect stemming from the diffusion of fixed-term contracts on productivity may emerge, due to weaker incentives to invest in firm-specific skills among both employers and employees (Lotti and Viviano 2012).

Italian business firms are characterized by strong differences in their structural conditions related to technology, positioning in global value chains, human resources management practices and productive strategies. These features strongly affect firms' labour productivity and the wages paid to workers. In this work, we 
Table 7 FE quantile estimates. Firms with less than 50 employees

\begin{tabular}{llllll}
\hline & $\mathrm{q} 10$ & $\mathrm{q} 25$ & $\mathrm{q} 50$ & $\mathrm{q} 75$ & $\mathrm{q} 90$ \\
\hline Panel A: lab productivity & & & & & \\
Share of FT contracts & $-0.372 * * *$ & $-0.269 * * *$ & $-0.195 * * *$ & $-0.133 * * *$ & $-0.051 *$ \\
& {$[0.040]$} & {$[0.023]$} & {$[0.015]$} & {$[0.021]$} & {$[0.031]$} \\
Other controls & Yes & Yes & Yes & Yes & Yes \\
Constant & $10.569 * * *$ & $10.781 * * *$ & $10.893 * * *$ & $11.129 * * *$ & $11.174 * * *$ \\
& {$[0.064]$} & {$[0.323]$} & {$[0.085]$} & {$[0.156]$} & {$[0.269]$} \\
N of Obs & 6443 & 6443 & 6443 & 6443 & 6443 \\
R2 & 0.647 & 0.664 & 0.666 & 0.661 & 0.654 \\
Panel B: wages & & & & & \\
Share of FT contracts & $-0.482 * * *$ & $-0.368 * * *$ & $-0.297 * * *$ & $-0.203 * * *$ & $-0.135 * * *$ \\
& {$[0.047]$} & {$[0.036]$} & {$[0.009]$} & {$[0.022]$} & {$[0.022]$} \\
Other controls & Yes & Yes & Yes & Yes & Yes \\
Constant & $10.542 * * *$ & $10.698 * * *$ & $10.737 * * *$ & $10.905 * * *$ & $11.416 * * *$ \\
& {$[0.050]$} & {$[0.074]$} & {$[0.031]$} & {$[0.209]$} & {$[0.548]$} \\
N of Obs & 6487 & 6487 & 6487 & 6487 & 6487 \\
R2 & 0.756 & 0.776 & 0.779 & 0.773 & 0.762 \\
\hline
\end{tabular}

RIL-INAPP 2007-2010-2015 longitudinal sample. Other control variables: employment composition (gender, executives, blue collar, white collar, trained, hirings, immigrants), vacancy, product innovation, process innovation, mergers and acquisitions, firms' age, sector of activity, macro-region, ecc), employers' membership, performance related pay. Robust (boostrapped) standard errors in parentheses; *** $p<0.01, * * p<0.05, * p<0.1$

shed light on the links between firms' use of flexible labour, labour productivity and wages and emphasize the existence of heterogeneous effects among firms.

Temporary employment can be used by firms to deal with unexpected fluctuations in demand, to screen for regular employment or to permanently staff positions. If it is used for the first two reasons, we observe a positive association between temporary employment and labour productivity because the detrimental effect on knowledge accumulation might be counterbalanced by better selection of more productive workers or accommodating to demand fluctuations. If firms systematically use temporary employees to staff positions, there will likely be a reduction in labour productivity due to disinvestment in human capital and weakening of the firm's organizational capabilities. Our analysis provides evidence of a prevalence of the third mechanism in all but firms at the top of the labour productivity distribution.

Using both the pooled quantile techniques (Santos Silva technique) and a quantile fixed effects approach (Canay technique), we find a strong and negative relationship between the share of temporary employees at the firm level, and both labour productivity and wages. It emerges that the lower productivity of temporary employment is compensated by lower labour costs. This general relationship changes with average firm productivity and average firm costs. An increasing share of temporary employment is more detrimental to labour productivity in low productive firms than in high-productive firms. In the most productive firms - in the 90th quantile - a higher share of temporary employment is not associated to lower labour productivity, while 
for firms in the 10th and 25th quantiles, a small increase in temporary employment in the workforce is associated negatively to firm productivity.

Focusing on wages, we show that temporary employment is associated with lower labour costs, and this effect is stronger in low-paying than in high-paying firms. Finally, we focused on small firms-with less than 50 employees-where most of these relationships are confirmed. A variation in the workforce composition towards more temporary employment affects labour productivity even in the most productive small firms and reduces labour productivity. In this perspective and comparing small and medium-large high productive firms, we find that use of temporary employment reduces labour productivity mostly in small firms.

Some lessons can be drawn from our analysis. Intensive use of short-term work arrangements weakens labour productivity mainly in low productive firms and might enforce a vicious cycle of low-productivity among low productive firms increasing the dualism in the Italian productive system towards a small cluster of high-productive firms coexisting with a large group of low-productive/low-paying firms. Policies encouraging flexible labour could weaken Italian business firms by promoting a neodualist tendency and potentially reinforcing the vicious-cycle of low-productivitylow-wages, with possible distributional consequences.

Funding Open access funding provided by Università degli Studi di Bari Aldo Moro within the CRUICARE Agreement.

Open Access This article is licensed under a Creative Commons Attribution 4.0 International License, which permits use, sharing, adaptation, distribution and reproduction in any medium or format, as long as you give appropriate credit to the original author(s) and the source, provide a link to the Creative Commons licence, and indicate if changes were made. The images or other third party material in this article are included in the article's Creative Commons licence, unless indicated otherwise in a credit line to the material. If material is not included in the article's Creative Commons licence and your intended use is not permitted by statutory regulation or exceeds the permitted use, you will need to obtain permission directly from the copyright holder. To view a copy of this licence, visit http://creativecommons.org/licenses/by/4.0/.

\section{Appendix}

See Tables 8, 9, 10, 11, 12, 13, 14 .

Table 8 Labour productivity and wages by quantiles and year (in logarithms). Cross-sectional sample

\begin{tabular}{lrrrrrrr}
\hline & \multicolumn{2}{l}{ Labour Productivity $(\log )$} & & \multicolumn{2}{l}{ Wages (log) } \\
\cline { 2 - 3 } \cline { 7 - 8 } & 2007 & 2010 & 2015 & & 2007 & 2010 & 2015 \\
\hline Mean & 10.69 & 10.68 & 10.52 & & 10.20 & 10.21 & 10.15 \\
q10 & 9.93 & 9.83 & 9.54 & 9.58 & 9.54 & 9.38 \\
q25 & 10.37 & 10.29 & 10.13 & & 9.96 & 9.98 & 9.91 \\
q50 & 10.74 & 10.67 & 10.60 & & 10.28 & 10.30 & 10.30 \\
q75 & 11.09 & 11.07 & 10.98 & & 10.53 & 10.56 & 10.58 \\
q90 & 11.56 & 11.63 & 11.47 & & 10.78 & 10.82 & 10.87 \\
\hline
\end{tabular}

RIL-AIDA 2007-2010-2015. Sampling weights applied 
Table 9 Share of temporary employees by main quantiles. Cross sectional sample

\begin{tabular}{|c|c|c|c|c|c|c|}
\hline & \multicolumn{2}{|l|}{2007} & \multicolumn{2}{|l|}{2010} & \multicolumn{2}{|l|}{2015} \\
\hline & Mean & $\mathrm{SD}$ & Mean & SD & Mean & SD \\
\hline \multicolumn{7}{|c|}{ Labor productivity } \\
\hline 1 quantile & 0.19 & 0.31 & 0.19 & 0.32 & 0.1 & 0.22 \\
\hline 2 quantile & 0.13 & 0.25 & 0.13 & 0.24 & 0.1 & 0.21 \\
\hline 3 quantile & 0.11 & 0.21 & 0.1 & 0.18 & 0.06 & 0.15 \\
\hline 4 quantile & 0.09 & 0.19 & 0.07 & 0.16 & 0.06 & 0.15 \\
\hline 5 quantile & 0.08 & 0.22 & 0.08 & 0.2 & 0.05 & 0.15 \\
\hline \multicolumn{7}{|l|}{ Labour costs } \\
\hline 1 quantile & 0.23 & 0.36 & 0.23 & 0.34 & 0.13 & 0.26 \\
\hline 2 quantile & 0.14 & 0.26 & 0.15 & 0.26 & 0.09 & 0.2 \\
\hline 3 quantile & 0.11 & 0.19 & 0.07 & 0.15 & 0.06 & 0.14 \\
\hline 4 quantile & 0.08 & 0.15 & 0.06 & 0.14 & 0.04 & 0.11 \\
\hline 5 quantile & 0.04 & 0.1 & 0.05 & 0.13 & 0.04 & 0.12 \\
\hline
\end{tabular}

RIL-AIDA 2007-2010-2015. Sampling weights applied

Table 10 Sample characteristics by year. Longitudinal sample RIL-AIDA

\begin{tabular}{|c|c|c|c|c|c|c|c|c|}
\hline & \multicolumn{2}{|l|}{2007} & \multicolumn{2}{|l|}{2010} & \multicolumn{2}{|l|}{2015} & \multicolumn{2}{|c|}{ Whole period } \\
\hline & Mean* & Std dev & Mean* & Std dev & Mean* & Std dev & Mean & Std dev \\
\hline$\%$ FT contracts & 10.5 & 0.21 & 10.6 & 0.20 & 0.07 & 0.18 & 9.2 & 0.20 \\
\hline$\%$ executives & 3.6 & 0.11 & 3.3 & 0.10 & 0.05 & 0.15 & 4.1 & 0.12 \\
\hline \%withe collar & 44.1 & 0.37 & 44.8 & 0.37 & 0.54 & 0.37 & 47.7 & 0.37 \\
\hline$\%$ blue collar & 52.1 & 0.37 & 51.9 & 0.38 & 0.41 & 0.38 & 48.2 & 0.38 \\
\hline$\%$ female & 37.3 & 0.33 & 42.2 & 0.33 & 0.44 & 0.35 & 41.3 & 0.34 \\
\hline$\%$ trained & 19.6 & 0.35 & 18.0 & 0.33 & 0.28 & 0.41 & 22.1 & 0.37 \\
\hline vacancy & 15.4 & 0.36 & 6.8 & 0.25 & 0.05 & 0.22 & 8.9 & 0.28 \\
\hline ln (n of employees) & 1.95 & 1.19 & 1.73 & 1.16 & 1.55 & 1.09 & 1.74 & 1.16 \\
\hline $\ln$ (physical capital pc) & 9.82 & 1.50 & 9.96 & 1.73 & 9.80 & 1.97 & 9.86 & 1.75 \\
\hline Process innovation & 34.8 & 0.48 & 25.6 & 0.44 & 0.26 & 0.44 & 28.7 & 0.45 \\
\hline Product innovation & 54.5 & 0.50 & 37.3 & 0.48 & 0.33 & 0.47 & 41.3 & 0.49 \\
\hline Employers' association & 54.0 & 0.50 & 49.2 & 0.50 & 0.49 & 0.50 & 50.5 & 0.50 \\
\hline Merger and acquistion & 1.2 & 0.11 & 3.9 & 0.19 & 0.03 & 0.16 & 2.6 & 0.16 \\
\hline Performance related pay & 4.1 & 0.20 & 4.1 & 0.20 & 0.03 & 0.18 & 3.9 & 0.19 \\
\hline Foreign ownership & 1.0 & 0.10 & 0.8 & 0.09 & 0.01 & 0.09 & 0.9 & 0.09 \\
\hline North West & 35.1 & 0.48 & 30.1 & 0.46 & 0.39 & 0.49 & 35.0 & 0.48 \\
\hline North East & 23.0 & 0.42 & 25.7 & 0.44 & 0.26 & 0.44 & 25.0 & 0.43 \\
\hline Centre & 22.4 & 0.42 & 26.3 & 0.44 & 0.19 & 0.39 & 22.5 & 0.42 \\
\hline South & 19.4 & 0.40 & 17.9 & 0.38 & 0.16 & 0.36 & 17.6 & 0.38 \\
\hline $\mathrm{N}$ of Obs & 2668 & & 2824 & & 2697 & & 8189 & \\
\hline
\end{tabular}

RIL-AIDA 2007-2010-2015 longitudinal sample. Sampling weights applied. * percent values 
Table 11 Sample characteristics by quantiles of labour productivity

\begin{tabular}{lcllll}
\hline & 1 quantile & 2 quantile & 3 quantile & 4 quantile & 5 quantile \\
\hline$\%$ executives & $4.1 \%$ & $4.3 \%$ & $2.1 \%$ & $3.6 \%$ & $6.3 \%$ \\
$\%$ withe collar & $48.1 \%$ & $45.7 \%$ & $44.7 \%$ & $47.5 \%$ & $52.4 \%$ \\
$\%$ blue collar & $47.8 \%$ & $49.8 \%$ & $53.2 \%$ & $49.1 \%$ & $41.1 \%$ \\
$\%$ female & $52.0 \%$ & $46.8 \%$ & $36.6 \%$ & $35.7 \%$ & $35.4 \%$ \\
$\%$ trained & $16.3 \%$ & $23.7 \%$ & $21.7 \%$ & $25 \%$ & $23.8 \%$ \\
Vacancy & $4.5 \%$ & $8 \%$ & $7.5 \%$ & $12.7 \%$ & $11.6 \%$ \\
N of employees & 8.11 & 11.87 & 15.46 & 17.12 & 19.32 \\
ln(physical capital pc) & 9.61 & 9.23 & 9.63 & 10.04 & 10.78 \\
Process innovation & $25.5 \%$ & $24.5 \%$ & $32 \%$ & $32.4 \%$ & $28.9 \%$ \\
Product innovation & $37.6 \%$ & $40.1 \%$ & $42.4 \%$ & $43.2 \%$ & $43.2 \%$ \\
Employers' association & $42.9 \%$ & $48.9 \%$ & $54.5 \%$ & $55.5 \%$ & $50.5 \%$ \\
Merger and acquisition & $0.6 \%$ & $1.2 \%$ & $2.6 \%$ & $3.9 \%$ & $4.5 \%$ \\
Performance related pay & $1.6 \%$ & $3 \%$ & $3.4 \%$ & $4.9 \%$ & $6.3 \%$ \\
Foreign ownership & $0.1 \%$ & $0.5 \%$ & $0.4 \%$ & $1.3 \%$ & $2.2 \%$ \\
North West & $27.3 \%$ & $33.5 \%$ & $36 \%$ & $34.7 \%$ & $43.3 \%$ \\
North East & $23.4 \%$ & $19.7 \%$ & $27.2 \%$ & $29.4 \%$ & $25.2 \%$ \\
Centre & $24.3 \%$ & $25.7 \%$ & $22.5 \%$ & $19.4 \%$ & $20.5 \%$ \\
South & $24.9 \%$ & $21 \%$ & $14.3 \%$ & $16.5 \%$ & $11 \%$ \\
\hline
\end{tabular}

RIL-AIDA 2007-2010-2015 longitudinal sample. Sampling weights applied

Table 12 Sample characteristics by quantiles of average wage

\begin{tabular}{lclcll}
\hline & 1 quantile & 2 quantile & 3 quantile & 4 quantile & 5 quantile \\
\hline \% executives & $4.3 \%$ & $2.6 \%$ & $2.9 \%$ & $2.5 \%$ & $8.2 \%$ \\
$\%$ withe collar & $46.5 \%$ & $44.9 \%$ & $45.1 \%$ & $50.5 \%$ & $51.3 \%$ \\
$\%$ blue collar & $49.2 \%$ & $52.5 \%$ & $51.9 \%$ & $46.9 \%$ & $40.4 \%$ \\
$\%$ female & $53.6 \%$ & $46.4 \%$ & $41.1 \%$ & $34.6 \%$ & $30.9 \%$ \\
$\%$ trained & $16.3 \%$ & $23.8 \%$ & $21.7 \%$ & $25.1 \%$ & $23.8 \%$ \\
Vacancy & $7.56 \%$ & $8.6 \%$ & $6.3 \%$ & $10.1 \%$ & $11.7 \%$ \\
N of employees & 6.59 & 9.61 & 12.90 & 18.08 & 24.65 \\
ln (physical capital pc) & 9.85 & 9.69 & 9.72 & 9.86 & 10.16 \\
Process innovation & $29.5 \%$ & $24.3 \%$ & $28.8 \%$ & $31.5 \%$ & $29.1 \%$ \\
Product innovation & $41.9 \%$ & $39.2 \%$ & $42.4 \%$ & $42 \%$ & $40.8 \%$ \\
Employers' association & $45.6 \%$ & $45.5 \%$ & $46.6 \%$ & $55.9 \%$ & $58.7 \%$ \\
Merger and acquisistion & $0.3 \%$ & $2.7 \%$ & $1.6 \%$ & $3.4 \%$ & $4.8 \%$ \\
Performance related pay & $0.9 \%$ & $2 \%$ & $2.3 \%$ & $5.1 \%$ & $8.9 \%$ \\
Foreign ownership & $0.01 \%$ & $0.1 \%$ & $0.4 \%$ & $0.7 \%$ & $3.2 \%$ \\
North West & $24.1 \%$ & $28.8 \%$ & $38.3 \%$ & $42.9 \%$ & $40.7 \%$ \\
North East & $22.9 \%$ & $21.8 \%$ & $25.6 \%$ & $26.4 \%$ & $28 \%$ \\
Centre & $26.1 \%$ & $28.9 \%$ & $17.7 \%$ & $19 \%$ & $20.7 \%$ \\
South & $26.8 \%$ & $20.4 \%$ & $18.3 \%$ & $11.7 \%$ & $10.6 \%$ \\
\hline
\end{tabular}

RIL-INAPP 2007-2010-2015 longitudinal sample. Sampling weights applied 


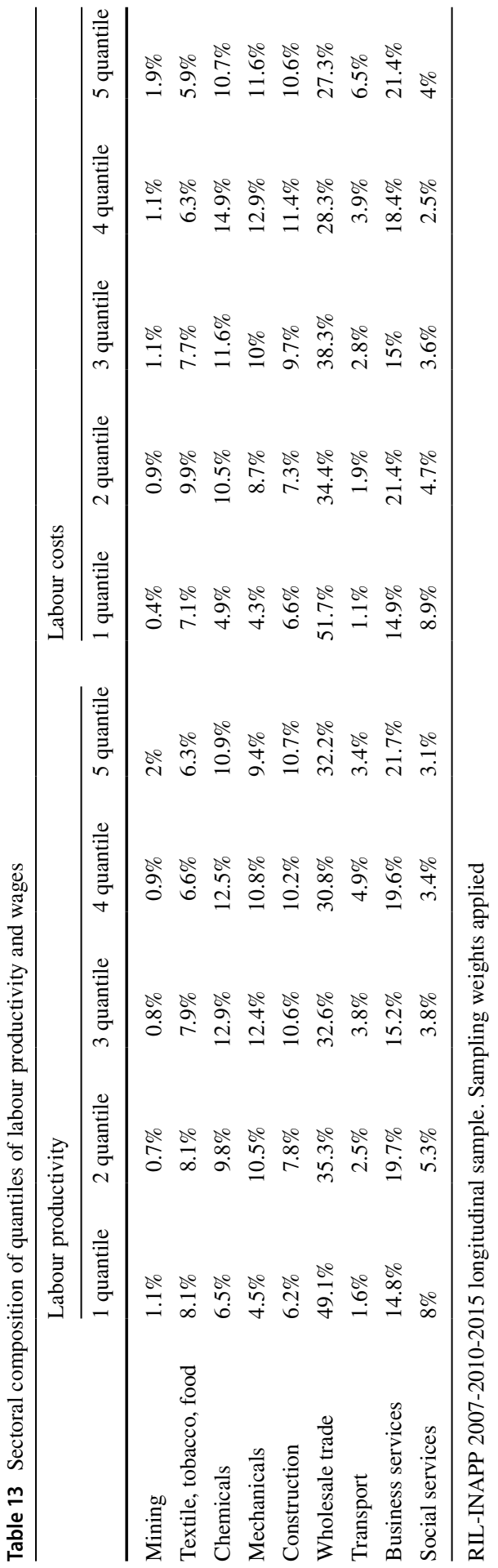


Table 14 Pooled quantile estimates (Parente and Santos Silva technique). Cross sectional sample

\begin{tabular}{|c|c|c|c|c|c|c|}
\hline & q10 & $\mathrm{q} 25$ & $\mathrm{q} 50$ & $\mathrm{q} 75$ & q90 & OLS \\
\hline \multicolumn{7}{|l|}{ Panel A: lab productivity } \\
\hline Share of FT contracts & $\begin{array}{l}-0.617 * * * \\
{[0.049]}\end{array}$ & $\begin{array}{l}-0.449 * * * \\
{[0.028]}\end{array}$ & $\begin{array}{l}-0.322 * * * \\
{[0.021]}\end{array}$ & $\begin{array}{l}-0.217 * * * \\
{[0.025]}\end{array}$ & $\begin{array}{l}-0.113^{* * *} \\
{[0.035]}\end{array}$ & $\begin{array}{l}-0.347 * * * \\
{[0.025]}\end{array}$ \\
\hline Year 2010 & $\begin{array}{l}-0.050^{* * *} \\
{[0.013]}\end{array}$ & $\begin{array}{l}-0.036^{* * *} \\
{[0.008]}\end{array}$ & $\begin{array}{l}-0.044 * * * \\
{[0.006]}\end{array}$ & $\begin{array}{l}-0.043^{* * *} \\
{[0.007]}\end{array}$ & $\begin{array}{l}-0.048^{* * *} \\
{[0.012]}\end{array}$ & $\begin{array}{l}-0.034 * * * \\
{[0.007]}\end{array}$ \\
\hline Year 2014 & $\begin{array}{l}-0.091 * * * \\
{[0.013]}\end{array}$ & $\begin{array}{l}-0.062 * * * \\
{[0.008]}\end{array}$ & $\begin{array}{l}-0.057^{* * * *} \\
{[0.007]}\end{array}$ & $\begin{array}{l}-0.032^{* * * *} \\
{[0.008]}\end{array}$ & $\begin{array}{l}-0.01 \\
{[0.013]}\end{array}$ & $\begin{array}{l}-0.056^{* * *} \\
{[0.008]}\end{array}$ \\
\hline Other controls & Yes & Yes & Yes & Yes & Yes & Yes \\
\hline Constant & $\begin{array}{l}8.750 * * * \\
{[0.153]}\end{array}$ & $\begin{array}{l}9.261 * * * \\
{[0.093]}\end{array}$ & $\begin{array}{l}9.622 * * * \\
{[0.136]}\end{array}$ & $\begin{array}{l}9.827 * * * \\
{[0.093]}\end{array}$ & $\begin{array}{l}10.471 * * * \\
{[0.118]}\end{array}$ & $\begin{array}{l}9.635 * * * \\
{[0.128]}\end{array}$ \\
\hline $\mathrm{N}$ of Obs & 34835 & 34835 & 34835 & 34835 & 34835 & 34835 \\
\hline $\mathrm{R} 2$ & 0.224 & 0.253 & 0.265 & 0.248 & 0.218 & 0.267 \\
\hline \multicolumn{7}{|l|}{ Panel A: wages } \\
\hline Share of FT contracts & $\begin{array}{l}-0.760^{* * *} \\
{[0.031]}\end{array}$ & $\begin{array}{l}-0.606^{* * *} \\
{[0.021]}\end{array}$ & $\begin{array}{l}-0.489 * * * \\
{[0.015]}\end{array}$ & $\begin{array}{l}-0.351^{* * *} \\
{[0.018]}\end{array}$ & $\begin{array}{l}-0.195^{* * *} \\
{[0.028]}\end{array}$ & $\begin{array}{l}-0.508 * * * \\
{[0.023]}\end{array}$ \\
\hline Year 2010 & $\begin{array}{l}0.023 * * * \\
{[0.009]}\end{array}$ & $\begin{array}{l}0.021 * * * \\
{[0.005]}\end{array}$ & $\begin{array}{l}0.026 * * * \\
{[0.004]}\end{array}$ & $\begin{array}{l}0.036 * * * \\
{[0.004]}\end{array}$ & $\begin{array}{l}0.043 * * * \\
{[0.006]}\end{array}$ & $\begin{array}{l}0.036 * * * \\
{[0.006]}\end{array}$ \\
\hline Year 2014 & $\begin{array}{l}-0.012 \\
{[0.009]}\end{array}$ & $\begin{array}{l}0.007 \\
{[0.005]}\end{array}$ & $\begin{array}{l}0.025 * * * \\
{[0.004]}\end{array}$ & $\begin{array}{l}0.058 * * * \\
{[0.004]}\end{array}$ & $\begin{array}{l}0.096^{* * * *} \\
{[0.008]}\end{array}$ & $\begin{array}{l}0.035 * * * \\
{[0.006]}\end{array}$ \\
\hline Other controls & Yes & Yes & Yes & Yes & Yes & Yes \\
\hline Constant & $\begin{array}{l}8.793 * * * \\
{[0.237}\end{array}$ & $\begin{array}{l}9.493 * * * \\
{[0.158}\end{array}$ & $\begin{array}{l}9.918 * * * \\
{[0.103}\end{array}$ & $\begin{array}{l}10.269 * * * \\
{[0.045}\end{array}$ & $\begin{array}{l}10.375^{* * *} \\
{[0.074}\end{array}$ & $\begin{array}{l}9.574 * * * \\
{[0.106]}\end{array}$ \\
\hline $\mathrm{N}$ of Obs & 35234 & 35234 & 35234 & 35234 & 35234 & 35234 \\
\hline $\mathrm{R} 2$ & 0.237 & 0.261 & 0.259 & 0.23 & 0.175 & 0.272 \\
\hline
\end{tabular}

RIL-INAPP 2007-2010-2015 cross sectional sample. Other control variables: employment composition, (gender, executives, blue collar, white collar, trained, hirings, immigrants), vacancy, product innovation, process innovation, merger and acquisitions, firms' age, sector of activity, macro-region, employers' membership, performance related pay. Robust (booststrapped) standard errors in parentheses: $* * *$ $p<0.01, * * p<0.05, * p<0.1$

\section{References}

Abowd, J. M., Haltiwanger, J., Jarmin, R., Lane, J., Lengermann, P., McCue, K., McKinney, K., \& Sandusky, K. (2005) "The Relation among Human Capital, Productivity, and Market Value: Building Up from Micro Evidence.” In Measuring Capital in the New Economy, ed. Carol Corrado, John Haltiwanger, and Daniel Sichel, 153-98. Chicago and London: University of Chicago Press.

Abraham, K. G., \& Taylor, S. K. (1996). Firms' use of outside contractors: theory and evidence. Journal of Labor Economics, 14(3), 394-424.

Acemoglu, D. (1997). Training and innovation in an imperfect labour market. Review of Economic Studies, 64, 445-464.

Acemoglu, D. (2002). (2002) Technical change, inequality and the labor market. Journal of Economic Literature, 40(1), 7-72. 
Acemoglu, D., \& Pischke, S. (1998). Why do firms train? Theory and evidence. The Quarterly Journal of Economics, 113(1), 79-119.

Acemoglu, D., \& Pischke, S. (1999). Beyond becker: training in imperfect labour markets. Economic Journal, 109, 112-142.

Addison, J. T., \& Surfield, C. J. (2009). Atypical work and employment continuity. Industrial Relations: A Journal of Economy and Society, 48(4), 655-683.

Aleksynska, M., \& Berg, J. (2016). Firms' demand for temporary labour in developing countries: Necessity or strategy. Conditions of work and employment series: ILO.

Amuedo-Dorantes, C. (2000). Work transitions into and out of involuntary temporary employment in a segmented market: evidence from Spain. ILR Review, 53(2), 309-325.

Aoki, M. (1988). Information, incentives and bargaining in the Japanese economy. Cambridge: Cambridge University Press.

Arulampalam, W., Booth, A. L., \& Bryan, M. L. (2004). Training in Europe. Journal of the European Economic Association, 2(2-3), 346-360.

Arvanitis, S. (2005). Modes of labor flexibility at firm level: are there any implications for performance and innovation? Evidence for the Swiss economy. Industrial and Corporate Change, 14(6), 993-1016.

Autor, D. H. (2001). why do temporary help firms provide free general skills training? The Quarterly Journal of Economics, Oxford University Press, 116(4), 1409-1448.

Avdagic, S. (2015). Does deregulation work? Reassessing the unemployment effects of employment protection. British Journal of Industrial Relations, 53(1), 6-26.

Baccaro, L., \& Rei, D. (2007). Institutional determinants of unemployment in oecd countries: does the deregulatory view hold water? International Organization, 61, 527-569.

Bartelsman, E. J., \& Doms, M. (2000). Understanding productivity: Lessons from longitudinal microdata. Journal of Economic literature, 38(3), 569-594.

Bassanini, A., \& Ernst, E. (2002). Labour market regulation, industrial relations and technological regimes: a tale of comparative advantage. Industrial and Corporate Change, 11(3), 391-426.

Bassanini, A., Booth, A. L., Brunello, G., De Paola, M., \& Leuven, E. (2007) Workplace training in Europe, ZA DP, (1640).

Berton, F., Devicienti, F., \& Pacelli, L. (2011). Are temporary jobs a port of entry into permanent employment? Evidence from matched employer-employee. International Journal of Manpower, 32(8), 879-899.

Blanchard, O., \& Landier, A. (2002). The perverse effects of partial labour market reform: fixed-term contracts in France. The Economic Journal, 112(480), F214-F244.

Bloom, N., \& Van Reenen, J. (2007). Measuring and explaining management practices across firms and countries. The quarterly journal of Economics, 122(4), 1351-1408.

Boockmann, B., \& Hagen, T. (2008). Fixed-term contracts as sorting mechanisms: evidence from job durations in West Germany. Labour Economics, 15(5), 984-1005.

Booth, A. L., Francesconi, M., \& Frank, J. (2002). Temporary jobs: stepping stones or dead ends? The economic journal, 112, 480.

Brown, S., \& Sessions, J. G. (2005). Employee attitudes, earnings and fixed-term contracts: international evidence. Review of World Economics, 141(2), 296-317.

Brunello, G., Garibaldi, P., \& Wasmer, E. (Eds.). (2005). Education and training in Europe. Oxford: Oxford University Press.

Buchele, R., \& Christiansen, J. (1999). Employment and productivity growth in Europe and North America: the impact of labor market institutions. International Review of Applied Economics, 13(3), 313-332.

Bugamelli, M., Lotti, F., Amici, M., Ciapanna, E., Colonna, F., D’Amuri, F. \& Scoccianti, F. (2018) Productivity growth in Italy: a tale of a slow-motion change. No 422, Questioni di Economia e Finanza (Occasional Papers), Bank of Italy, Economic Research and International Relations Area.

Caballero, R. J., \& Hammour, M. L. (1994) On the time and efficiency of creative destruction. No 4768, NBER Working Papers, National Bureau of Economic Research, Inc.

Calligaris S., Del Gatto M., Hassan F., Ottaviano G. \& Schivardi F. (2016) "Italy's productivity conundrum. A study on resource misallocation in Italy", Discussion Papers No. 30, European Commission, DG ECF

Canay, I. A. (2011). A simple approach to quantile regression for panel data. The Econometrics Journal, 14(3), 368-386. 
Card, D., Cardoso, A. R., Heining, J., \& Kline, P. (2018). Firms and labor market inequality: evidence and some theory. Journal of Labor Economics, 36(S1), S13-S70.

Cetrulo, A., Cirillo, V., \& Guarascio, D. (2019). Weaker jobs, weaker innovation exploring the effects of temporary employment on new products. Applied Economics. https://doi.org/10.1080/00036 846.2019.1619015.

Chennells, L., \& Van Reenen, J. (2002). Technical change and the structure of employment and wages: A survey of the microeconometric evidence. Productivity, Inequality and the Digital Economy, MIT Press, Cambridge, MA, pp 175-223.

Collard-Wexler, A. (2006) Productivity Dispersion and Plant Selection in the ReadyMix Concrete Industry. Manuscript. New York University.

Damiani, M., Pompei, F., \& Ricci, A. (2016). Temporary employment protection and productivity growth in EU economies. International Labour Review, 155(4), 587-622.

Damiani, M., Pompei, F., \& Ricci, A. (2018). Labour shares, employment protection and unions in European economies. Socio-Economic Review. https://doi.org/10.1093/ser/mwy025.

De Stefano, V. (2014). A tale of oversimplification and deregulation: the mainstream approach to labour market segmentation and recent responses to the crisis in European Countries. Industrial Law Journal, 43(3), 253-285.

Dosi, G., Nelson, R., \& Winter, S. (Eds.). (2001). The nature and dynamics of organizational capabilities. Oxford: Oxford University Press.

Dosi, G., Faillo, M., \& Marengo, L. (2008). Organizational capabilities, patterns of knowledge accumulation and governance structures in business firms: an introduction. Organization Studies, 29, 1165-1185.

Dosi, G., Grazzi, M., Tomasi, C., \& Zeli, A. (2012). Turbulence underneath the big calm? The microevidence behind Italian productivity dynamics. Small Business Economics, 39(4), 1043-1067.

Dosi, G., Guarascio, D., Ricci, A., \& Virgillito, M. E. (2019) Neodualism in the Italian business firms: training, organizational capabilities and productivity distributions. Small Bus Econ (2019). https:// doi.org/10.1007/s11187-019-00295-X

Eaton, J., \& Kortum, S. (2002). Technology, geography, and trade. Econometrica, 70(5), 1741-1779.

Engellandt, A., \& Riphahn, R. T. (2005). Temporary contracts and employee effort. Labour economics, 12(3), 281-299.

Estevez-Abe, M., T. Iversen \& Soskice, D. (2001) "Social Protection and the Formation of Skills: A Reinterpretation of the Welfare State." In Varieties of Capitalism. The Institutional Foundations of Comparative Advantage, 145. Oxford Scholarship Online. https://doi.org/10.1093/0199247757 .003 .0004

European Commission (2007) Towards common principles of flexicurity: More and better jobs through flexibility and security. Luxembourg: Office for Official Publications of the European Communities.

Firpo, S., Fortin, N. M., \& Lemieux, T. (2009). Unconditional quantile regressions. Econometrica, 77(3), 953-973.

Foster, L., Grim, C., Haltiwanger, J., \& Wolf, Z. (2016). Firm-level dispersion in productivity: is the devil in the details? American Economic Review, 106(5), 95-98.

Garnero, A., Kampelmann, S., \& Rycx, F. (2014). Part-time work, wages, and productivity: evidence from Belgian matched panel data. ILR Review, 67(3), 926-954.

Gash, V. (2008). Bridge or trap? Temporary workers' transitions to unemployment and to the standard employment contract. European Sociological Review, 24(5), 651-668.

Gerfin, M., Lechner, M., \& Steiger, H. (2005). Does subsidised temporary employment get the unemployed back to work? An econometric analysis of two different schemes. Labour Economics, 12(6), 807-835.

Gibbons, R., \& Katz, L. F. (1991). Layoffs and lemons. Journal of labor Economics, 9(4), 351-380.

Güell, M., \& Petrongolo, B. (2007). How binding are legal limits? Transitions from temporary to permanent work in Spain. Labour Economics, 14(2), 153-183.

Hall, P. A., \& Soskice, D. (2001). Varieties of capitalism: the institutional foundations of comparative advantage. Oxford: Oxford University Press.

Haltiwanger, J. C., Lane, J. I., \& Spletzer, J. (1999). Productivity differences across employers: the roles of employer size, age, and human capital. American Economic Review, 89(2), 94-98.

Hortaçsu, A., \& Syverson, C. (2007). Cementing relationships: vertical integration, foreclosure, productivity, and prices. Journal of Political Economy, 115(2), 250-301.

Houseman, S. (2001). Why employers use flexible staffing arrangements: evidence from an establishment survey. Industrial and Labor Relations Review, 55(1), 149-170. 
Howell, D. R., Baker, D., Glyn, A., \& Schmitt, J. (2007). Are protective labor market institutions at the root of unemployment? A critical review of the evidence. Capitalism and Society, 2(1), 1-71.

Hoxha, S., \& Kleinknecht, A. (2020). When labour market rigidities are useful for innovation. Evidence from German IAB firm-level data. Research Policy, 49(7), 104066.

Ichniowski, C., \& Shaw, (2003). beyond incentive pay: insiders' estimates of the value of complementary human resource management practices. Journal of Economic Perspectives, 17(1), 155-180.

INAPP (2017) Nota metodologica Rilevazione su Imprese e Lavoro (RIL), https://inapp.org/sites/default/ files/RIL\%202015\%20Nota\%20Metodologica.pdf

International Labour Organization (2017) Global wage report 2016/17: Wage inequality in the workplace. $9789221309291[$ ISBN].

Kleinknecht, A. (2020). The (negative) impact of supply-side labour market reforms on productivity: an overview of the evidence. Cambridge Journal of Economics, 44(2), 445-464.

Kleinknecht, A., Oostendorp, R. M., Pradhan, M. P., \& Naastepad, C. W. M. (2006). Flexible labour, firm performance and the Dutch job creation miracle. International Review of Applied Economics, 20(2), 171-187.

Koenker, R., Bassett Jr, G. (1978). Regression quantiles. Econometrica: journal of the Econometric Society, 33-50.

Koenker, R., \& Xiao, Z. (2004). Unit root quantile autoregression inference. Journal of the American Statistical Association, 99(467), 775-787.

Layard, R., Nickell, S., \& Jackman, R. (1991). Unemployment: macroeconomic performance and the labour market. Oxford: Oxford University Press.

Lazear, E. P. (1986) Raids and Offer-Matching, Research in Labor Economics, ed. Ronald Ehrenberg, Vol. 8. pp. 141-165.

Lazear, E. P. (2000). Performance Pay and Productivity. American Economic Review, 90(5), 1346-61.

Linarello, A., \& Petrella, A. (2017). Productivity and reallocation: evidence from the universe of Italian firms. International Productivity Monitor, 32, 116-136.

Lorenz, E. (1992). Trust and the Flexible Firm: International Comparisons. Industrial Relations: A Journal ofEconomy and Society, 31, 455-472. https://doi.org/10.1111/j.1468-232X.1992.tb003 20.x.

Lotti, F., \& Viviano, E. (2012). Why hiring temporary workers. Rome: Banca d'Italia.

Lucidi, F., \& Kleinknecht, A. (2010). Little innovation, many jobs: an econometric analysis of the Italian labour productivity crisis. Cambridge Journal of Economics, 34(3), 525-546.

Machado, J. A., \& Mata, J. (2005). Counterfactual decomposition of changes in wage distributions using quantile regression. Journal of applied Econometrics, 20(4), 445-465.

Machado, J. A., \& Silva, J. S. (2000). Glejser's test revisited. Journal of Econometrics, 97(1), 189-202.

Maksimovic, V., \& Phillips, G. (2002). Do conglomerate firms allocate resources inefficiently across industries? Theory and evidence. The Journal of Finance, 57(2), 721-767.

Martin, J. P., \& Scarpetta, S. (2012). Setting it right: Employment protection, labour reallocation and productivity. De Economist, 160(2), 89-116.

McGinnity, F., Mertens, A., \& Gundert, S. (2005). A bad start? Fixed-term contracts and the transition from education to work in West Germany. European Sociological Review, 21(4), 359-374.

Melitz, M. J. (2003). The Impact of Trade on Intraindustry Reallocations and Aggregate Industry Productivity. Econometrica, 71(6), 1695-1725.

Michie, J., \& Sheehan, M. (1999). HRM practices, R\&D expenditure and innovative investment: evidence from the UK's 1990 workplace industrial relations survey (WIRS). Industrial and Corporate Change, $8(2), 211-234$.

Naastepad, C. W. M., \& Storm, S. (2006). The innovating firm in a societal context: labour-management relations and labour productivity (pp. 170-191). London: Managing Technology and Innovation. Routledge.

Nickell, S. (1997). Unemployment and labour market rigidities: Europe versus North America. Journal of Economic Perspectives, 11(3), 55-74.

Nickell, S., \& Layard, R. (1999). Labor market institutions and economic performance. Handbook of labor economics, 3, 3029-3084.

Nickell, S., Nunziata, L., \& Ochel, W. (2005) Unemployment in the OECD since the 1960s. What do we know? Economic Journal, 115(500), 1-27.

OECD. (1994). OECD jobs study: facts, analysis, strategy. Paris: OECD Pubblication Centre. 
OECD (2019). Strengthening active labour market policies in Italy. Connecting People with Jobs, OECD Publishing, Paris, . https://doi.org/10.1787/160a3c28-en.

OECD (1999). OECD Employment Outlook 1999: June, OECD Publishing, Paris. https://doi. org/10.1787/empl_outlook-1999-en.

OECD (2003). OECD Employment Outlook: Towards more and better jobs. OECD Publishing, Paris, https://doi.org/10.1787/empl_outlook-2003-en.

Osterman, P. (2018). In search of the high road: meaning and evidence. ILR Review, 71(1), 3-34.

Parente, P. M., \& Silva, J. M. S. (2016). Quantile regression with clustered data. Journal of Econometric Methods, 5(1), 1-15.

Piasna, A., \& Myant, M. (2017). Myths of Employment Deregulation: How It neither Creates Jobs nor Reduces Labour Market Segmentation. Brussels: ETUI.

Powell, D. (2016). Quantile regression with nonadditive fixed effects. Quantile Treatment Effects, Unpublished manuscript, available at: https://works.bepress.com/david_powell/1/

Ricci, A., \& Waldmann, R. (2015). Firm financed training and pareto improving firing taxes. Economia Politica, 32(2), 201-220.

Scarpetta, S. (1996). Assessing the role of labour market policies and institutional settings on unemployment: across country study, OECD economic studies 26. Paris: OECD.

Schmitz, J. A. (2005). What determines productivity? Lessons from the dramatic recovery of the US and Canadian Iron ore industries following their early 1980 crisis. Journal of Political Economy, $113(3), 582-625$.

Schoar, A. (2002). Effects of corporate diversification on productivity. The Journal of Finance, 57(6), 2379-2403.

Schömann I. (2014) replace with: ETUI contributors. (2020, March 25). Labour law reforms in Europe: adjusting employment protection legislation for the worse? In ETUI, The European Trade Union Institute.

Siebert, H. (1997). Labor market rigidities: at the root of unemployment in Europe. Journal of Economic Perspectives, 11(3), 37-54.

Jaimovich, N. \& Siu, H. E. (2012). "The trend is the cycle: job polarization and jobless recoveries". NBER Working Paper, 18334

Syverson, C. (2004). Market structure and productivity: a concrete example. Journal of Political Economy, 112(6), 1181-1222.

Syverson, C. (2011). What determines productivity? Journal of Economic Literature, 49(2), 326-365.

Teece, D. (2019). A capability theory of the firm: an economics and (Strategic) management perspective. New Zealand Economic Papers, 53(1), 1-43.

Vidal, M., \& Tigges, L. M. (2009). Temporary employment and strategic staffing in the manufacturing sector. Industrial Relations: A Journal of Economy and Society, 48(1), 55-72.

Waldman, M. (1984). Job assignments, signalling, and efficiency. The RAND Journal of Economics, 15(2), 255-267.

Wang, R., \& Weiss, A. (1998). Probation, layoffs, and wage-tenure profiles: a sorting explanation. Labour Economics, 5(3), 359-383.

Wasmer, E. (2006). General versus specific skills in labor markets with search frictions and firing costs. American Economic Review, 96(3), 811-831.

Winter, S. G. (1987) Knowledge and competence as strategic assets. In D. J. Teece (Ed.), The competitive challenge-Strategies for Industrial Innovation and Renewal. Cambridge, MA: Ballinger.

Zwick, T. (2006). The impact of training intensity on establishment productivity. Industrial relations: $a$ journal of economy and society, 45(1), 26-46.

Publisher's Note Springer Nature remains neutral with regard to jurisdictional claims in published maps and institutional affiliations. 